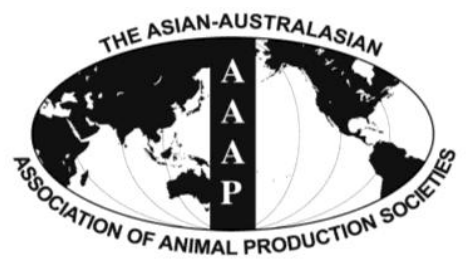

Asian-Aust. J. Anim. Sci.

Vol. 25, No. 12 : 1775-1779 December 2012

http://dx.doi.org/10.5713/ajas.2012.12361

www.ajas.info

pISSN 1011-2367 elSSN 1976-5517

\title{
Colour Changes in Meat of Foals as Affected by Slaughtering Age and Post-thawing Time
}

\author{
P. De Palo*, A. Maggiolino, P. Centoducati and A. Tateo \\ Department of Public Health and Animal Science, S.P. per Casamassima, km 3, 70010 Valenzano (BA), Italy
}

\begin{abstract}
The aim of the present work was to investigate how colour changes of foal meat can vary after thawing out in relation to the slaughtering age of the horses and to the post-thawing time. Eighteen Italian Heavy Draught Horse (IHDH) foals were used for the trial. They were subdivided in three groups according to their slaughtering age (6,11 and 18 months). Two different surfaces were investigated for each sample: a fresh cut surface (daily renewed cutting surface: DRCS), and not-renewed cutting surface (NRCS). The redness of both investigated surfaces increased with slaughtering age $(\mathrm{p}<0.01)$. Moreover, this parameter decreased during post-thawing time $(\mathrm{p}<0.01)$ only on the NRCS, probably due to the myoglobin oxidation processes. Colour is an important visual cue denoting perceived quality by consumers. So, by a chromatic perspective the thawed meat of IHDH foals slaughtered at 6 and 11 months proved to be that which best meets the market requirements. (Key Words: Age at Slaughtering, Foal Meat, Meat Colour)
\end{abstract}

\section{INTRODUCTION}

The characteristics of meat which can be visually evaluated by consumers are colour, texture and marbling. Smith et al. (2000) affirmed that market was affected by consumer's perception of some macroscopic meat aspects like colour. In fact, often consumers correlate these aspects to the product freshness. Although the quality perceived by consumers does not coincide with the objective quality, it can cause significant economic losses in the fresh meat market. Colour is an important visual cue denoting quality to consumers who prefer to purchase meat that is red rather than brown in colour (Jacob and Thomson, 2012). The main characteristics of meat affecting its colour are: myoglobin concentration, its chemical state, lipid oxidative status (Kannan et al., 2001), muscle structure (which depends on pH and marbling) (Brewer et al., 2001), microbial growth (Stivarius et al., 2002), oxygen consumption rate (Wulf and Wise, 1999) and drip losses (Choe et al., 2009). The factors affecting those characteristics are genetics, diet, age/weight at slaughter, pre-mortem handling, post-mortem conditions, and packaging (Mancini and Hunt, 2005).

In Italy, for many years efforts have been made to develop the national production of horse meat from both the

\footnotetext{
* Corresponding Author: Pasquale De Palo. Tel: +390805443919, Fax: +390804679925, E-mail: pasquale.depalo@uniba.it Submitted Jun. 26, 2012; Accepted Sept. 5, 2012; Revised Sept. 18, 2012
}

qualitative and quantitative points of view. Today the production of horse meat is obtained from breeds such as the Italian Heavy Draught Horse (IHDH), and studies of in vivo performance (Tateo et al., 2009) and of the quality of the carcasses (Tateo et al., 2005) have shown that animals of this breed are particularly suitable for meat production. The increased demand for horse meat on the Italian and European markets presents problems linked to ensuring continuous product availability during the year, and to welfare and health problems involved in the transport of the live animals. To bypass those problems, in the last years it is consolidated the practice of trading frozen horse carcasses. For these reasons it was decided to investigate how the colour of horse meat can vary after thawing in relation to the slaughtering age of the animals. The purpose of this was to establish the best slaughtering age in order to obtain meat with post-freezing colour properties acceptable to the consumer, also in relation to the post-thawing time. The present work investigates thawed and unpackaged foal meat as a preliminary and useful study for further researches on vacuum and modified atmosphere packaged fresh and thawed horse meat.

\section{MATERIALS AND METHODS}

\section{Animals}

A total of 18 males IHDH breed foals were employed in 
the study. At birth they were randomly subdivided in 3 groups according to age at slaughtering: $6 \mathrm{mo}$ old, $11 \mathrm{mo}$ old and 18 mo old. The foals assumed colostrum and suckled naturally and, from their second day of life, they followed their dams to the grazing areas for almost $6 \mathrm{~h} / \mathrm{d}$. The foals were weaned at 4 mo old, and then were kept in 3 indoor stalls (one for each experimental group), with a surface area of $6 \mathrm{~m}^{2}$ per head. Each group received a ration subdivided in three daily meals. The composition of the feed administered was the same for all the experimental trial and it was composed with $35 \%$ of oat hay and $65 \%$ of commercial feed (rolled corn 33\%, soybean meal $21 \%$, wheat bran $17 \%$, rolled barley $13.5 \%$, rolled oats $13.5 \%$, vitamin and mineral integration $2 \%$.

\section{Slaughtering and treatment of the samples}

The slaughtering operations were carried out in national slaughterhouses. After slaughtering the carcasses were kept in a chilling room at $4^{\circ} \mathrm{C}$ for $48 \mathrm{~h}$. After this, samples of Longissimus dorsi (LD) muscle between 13th and 18th thoracic vertebra (about $500 \mathrm{~g}$ for each sample) were taken for analysis. These samples were held at $4{ }^{\circ} \mathrm{C}$ during transport to the laboratory where, within two hours, samples were vacuum packaged and frozen at $-20^{\circ} \mathrm{C}$ for $30 \mathrm{~d}$. Thawing was carried out at $4^{\circ} \mathrm{C}$ for $24 \mathrm{~h}$. The samples were subsequently inserted in 5-cm long and $10-\mathrm{cm}$-diameter polyvinyl chloride (PVC) cylinders, in such a way that the muscular fibres ran parallel to the axis of the cylinder. On one side of the cylinder a fresh cut was made, which was not renewed. The non-renewed cut surface (NRCS) was aligned to the edge of the pipe. On the surface of the other side of the cylinder, a cut (1-cm tick) was repeated daily (daily renewed cut surface; DRCS) immediately before making the tests. To facilitate the cut, made with a sterile scalpel. The meat sample exceeded the edge of the cylinder by $5 \mathrm{~cm}$ on this side (Tateo et al., 2007).

\section{Acidity, haematin concentration and instrumental colorimetry}

The $\mathrm{pH}$ values and instrumental colorimetry data were collected on for $4 \mathrm{~d}$ after thawing. The $\mathrm{pH}$ was measured with a portable $\mathrm{pH}$ meter provided with a puncture electrode (Forlab pH 710, Taranto, Italy). The colorimetric parameters were measured in triplicate, after turning the sample by $90^{\circ}$, in three different places, using a colorimeter (Minolta CR-300, Model CR-300, Minolta Co., Ltd, Osaka, Japan), with a $1 \mathrm{~cm}$ aperture, illuminant D65 and a $2^{\circ}$ viewing angle. The colour was expressed with the CIE Lab according to CIE system, measuring colour coordinates: lightness $\left(\mathrm{L}^{*}\right)$, redness $\left(\mathrm{a}^{*}\right)$ and yellowness $\left(\mathrm{b}^{*}\right)$. The standard white plate used for calibration had $\mathrm{L}^{*}=97.53$, a* $=0.13, \mathrm{~b}^{*}=1.43$. The arithmetic mean of the nine recordings obtained was used for further statistical analysis.
The coordinates $a^{*}$ and $b^{*}$ were used for the determination of the Chroma $(C)=\left(a^{2}+b^{2}\right)^{1 / 2}$ as indicated by Mancini et al., (2004) and Little (1975).

The colorimetric parameters were measured daily, during four post-thawing days, both on the NRCS (one side of the PVC pipe) and the DRCS surface. The colorimetric parameters of the freshly cut surface were recorded $30 \mathrm{~min}$ after the cut to let blooming. Immediately after thawing, a 5 $\mathrm{g}$ piece of meat was used to determine the acid haematin concentration, according to the spectrophotometric method of Hornsey (1956).

\section{Statistical analysis}

The data obtained were submitted to analysis of variance employing the Statistical Analysis System (SAS) General Linear Model (GLM) procedure (1998) considering as independent variables the age at slaughtering, the postthawing days, and the binary interactions between these factors. For a comparison of the averages, it was used the post hoc Tukey's test for repeated measures (SAS, 1998). All the results reported are expressed as least square means and standard errors considering each post-thawing day as repeated measure.

\section{RESULTS}

Lightness $\left(\mathrm{L}^{*}\right)$ values recorded on the NRCS surfaces (Table 1) of animals slaughtered at $6 \mathrm{mo}$ at the 4 th postthawing day were greater than older horses $(p<0.05)$. Redness $\left(a^{*}\right)$, on NRCS surfaces tended to decrease in all slaughtering ages investigated. In younger animals $a^{*}$ values at the day IV were lower than day I. In horses slaughtered at $11 \mathrm{mo} \mathrm{a}^{*}$ values decreased from the first to the third post-thawing day $(\mathrm{p}<0.01)$. In older animals redness recorded at the first day showed higher values than at the following days $(p<0.01)$. Moreover, meat obtained from younger animals, on NRCS surfaces revealed $a^{*}$ values lower than older animals at the first day $(\mathrm{p}<0.01)$ and lower than $18 \mathrm{mo}$ animals at the fourth day $(\mathrm{p}<0.01)$. At the first post thawing day, yellowness $\left(b^{*}\right)$ of the NRCS of meat belonging to horses slaughtered at 6 mo was lower than in the second and the third day $(\mathrm{p}<0.05)$. In 11 mo old animals, $b^{*}$ values recorded at the second and at the third day are greater than what observed at the first and fourth day $(\mathrm{p}<0.01)$. In horses slaughtered at $18 \mathrm{mo}$, these values at the fourth day are lower than the second $(\mathrm{p}<0.01)$ and the third day $(\mathrm{p}<0.05)$.

Lightness of DRCS (Table 2) in samples of animals slaughtered at $6 \mathrm{mo}$ at the first day was lower than the third day $(p<0.05)$. Moreover, from the second to the fourth postthawing day, the DRCS in meat of animals slaughtered at 6 mo showed greater lightness values $(p<0.01)$ than in the same surface of samples obtained by horses slaughtered at 
Table 1. Influence of slaughtering age on colorimetric parameters of not-renewed cutting surface (NRCS), $\mathrm{pH}$ and haematin (ppm) during the four post-thawing days (Least square means \pm standard error)

\begin{tabular}{|c|c|c|c|c|}
\hline $\begin{array}{c}\text { Storage } \\
\text { day }\end{array}$ & 6 months & 11 months & 18 months & SE \\
\hline & \multicolumn{4}{|c|}{ 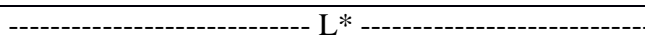 } \\
\hline I & 37.14 & 35.68 & 35.88 & \multirow[t]{4}{*}{1.51} \\
\hline II & 37.74 & 35.38 & 33.95 & \\
\hline III & 36.92 & 35.44 & 33.26 & \\
\hline IV & $37.34^{\mathrm{x}}$ & 34.44 & $32.40^{y}$ & \\
\hline I & $15.11^{\mathrm{A}, \mathrm{X}}$ & $17.85^{\mathrm{A}, \mathrm{Y}}$ & $17.35^{\mathrm{A}, \mathrm{Y}}$ & \multirow[t]{4}{*}{0.67} \\
\hline II & 13.29 & $14.42^{\mathrm{B}}$ & $13.98^{\mathrm{B}}$ & \\
\hline III & 12.00 & $11.12^{\mathrm{C}}$ & $12.92^{\mathrm{B}}$ & \\
\hline IV & $10.81^{\mathrm{B}, \mathrm{X}}$ & $12.42^{\mathrm{C}}$ & $13.95^{\mathrm{B}, \mathrm{Y}}$ & \\
\hline I & $2.88^{\mathrm{a}, \mathrm{x}}$ & $0.97^{\mathrm{A}, \mathrm{y}}$ & 2.00 & \multirow[t]{4}{*}{0.43} \\
\hline II & $4.98^{\mathrm{b}}$ & $4.95^{\mathrm{B}}$ & $3.88^{\mathrm{A}}$ & \\
\hline III & $5.00^{\mathrm{b}, \mathrm{x}}$ & $4.19^{\mathrm{B}}$ & $2.96^{\mathrm{a}, \mathrm{y}}$ & \\
\hline IV & $3.85^{\mathrm{Xx}}$ & $2.06^{\mathrm{A}, \mathrm{y}}$ & $0.58^{\mathrm{Bb}, \mathrm{Y}}$ & \\
\hline I & $116.78^{\mathrm{A}, \mathrm{X}}$ & $\begin{array}{c}163.45^{\mathrm{A}, \mathrm{Y}} \\
\end{array}$ & na ---------- $161.38^{\mathrm{A}, \mathrm{Y}}$ & \multirow[t]{4}{*}{9.02} \\
\hline II & $103.02^{\mathrm{A}}$ & $120.89^{\mathrm{B}}$ & $109.26^{\mathrm{B}}$ & \\
\hline III & 85.99 & $75.77^{\mathrm{C}}$ & $93.37^{\mathrm{B}}$ & \\
\hline IV & $69.45^{\mathrm{B}}$ & $89.39^{\mathrm{C}}$ & $102.30^{\mathrm{B}}$ & \\
\hline I & 5.58 & 5.60 & 5.67 & \multirow[t]{4}{*}{0.03} \\
\hline II & 5.52 & 5.62 & 5.66 & \\
\hline III & 5.50 & 5.61 & 5.62 & \\
\hline IV & 5.59 & 5.62 & 5.61 & \\
\hline & $137.70^{\mathrm{a}}$ & $187.48^{\mathrm{b}}$ & $196.71^{b}$ & 19.63 \\
\hline
\end{tabular}

Different letters in the same row show statistical differences (A, B: $\mathrm{p}<0.01 ; \mathrm{a}, \mathrm{b}: \mathrm{p}<0.05)$; different letters in the same line show statistical differences (X, Y: $\mathrm{p}<0.01 ; \mathrm{x}, \mathrm{y}: \mathrm{p}<0.05)$.

18 mo, Redness in all experimental days on 6 mo old animals is lower than other slaughtering ages $(p<0.01)$. DRCS of meat obtained by 18 mo old horses, at the third post thawing day showed lower yellowness values than the first post-thawing day $(\mathrm{p}<0.01)$. At the first post thawing day, meat of animals slaughtered at 6 mo showed greater $b^{*}$ values on the DRCS than the other slaughtering ages $(\mathrm{p}<0.01)$. At the third day and on the same surface, meat obtained by horses slaughtered at 18 mo showed lower yellowness values than animals slaughtered at 6 and 11 mo $(\mathrm{p}<0.01)$. Moreover, at the fourth day, yellowness values recorded on DRCS of meat obtained by horses slaughtered at 18 mo were lower than in samples belonging to horses slaughtered at $11 \mathrm{mo}(\mathrm{p}<0.05)$. The chroma, on NRCS tend to decrease during post thawing time in all the investigated ages. At the fourth day, in younger animals, chroma revealed lower values than at the first two post thawing days $(p<0.01)$. In samples from horses slaughtered at $11 \mathrm{mo}$
Table 2. Influence of slaughtering age on colorimetric parameters of daily renewed cutting surface (DRCS) during the four postthawing days (Least square means \pm standard error)

\begin{tabular}{|c|c|c|c|c|}
\hline $\begin{array}{c}\text { Storage } \\
\text { day }\end{array}$ & 6 months & 11 months & 18 months & SE \\
\hline & \multicolumn{4}{|c|}{ - } \\
\hline I & $37.11^{\mathrm{a}}$ & 35.58 & 34.37 & \multirow[t]{4}{*}{1.22} \\
\hline II & $41.13^{\mathrm{X}}$ & 38.96 & $35.15^{\mathrm{Y}}$ & \\
\hline III & $42.15^{\mathrm{b} ; \mathrm{X}}$ & 38.18 & $35.42^{\mathrm{Y}}$ & \\
\hline IV & $41.08^{\mathrm{X}}$ & 39.54 & $36.10^{\mathrm{Y}}$ & \\
\hline I & $15.08^{\mathrm{X}}$ & $17.90^{\mathrm{Y}}$ & $18.26^{\mathrm{Y}}$ & \multirow[t]{4}{*}{0.50} \\
\hline II & $14.31^{\mathrm{X}}$ & $16.92^{\mathrm{Y}}$ & $17.93^{\mathrm{Y}}$ & \\
\hline III & $14.35^{\mathrm{X}}$ & $16.93^{\mathrm{Y}}$ & $17.39^{\mathrm{Y}}$ & \\
\hline IV & $15.64^{\mathrm{x}}$ & $17.08^{\mathrm{Y}}$ & $17.74^{\mathrm{Y}}$ & \\
\hline I & $2.83^{\mathrm{X}}$ & $0.95^{\mathrm{Y}}$ & $1.22^{\mathrm{A} ; \mathrm{Y}}$ & \multirow[t]{4}{*}{0.43} \\
\hline II & 1.15 & 1.07 & 0.07 & \\
\hline III & $1.45^{\mathrm{X}}$ & $1.42^{\mathrm{X}}$ & $-0.35^{\mathrm{B} ; \mathrm{Y}}$ & \\
\hline \multirow[t]{2}{*}{ IV } & 1.20 & $1.41^{\mathrm{x}}$ & $0.08^{\mathrm{y}}$ & \\
\hline & & - & la --------- & 812 \\
\hline $\begin{array}{l}\text { I } \\
\text { II }\end{array}$ & $\begin{array}{l}118.87^{x} \\
106.32^{x}\end{array}$ & $\begin{array}{l}164.87^{1} \\
147.18^{Y}\end{array}$ & $\begin{array}{l}172.81^{1} \\
164.15^{Y}\end{array}$ & \multirow{3}{*}{8.12} \\
\hline III & $107.56^{\mathrm{X}}$ & $147.45^{\mathrm{Y}}$ & $154.94^{\mathrm{Y}}$ & \\
\hline IV & $125.77^{\mathrm{X}}$ & $151.63^{\mathrm{Y}}$ & $160.66^{\mathrm{Y}}$ & \\
\hline
\end{tabular}

Different letters in the same row show statistical differences (A, B: $\mathrm{p}<0.01 ; \mathrm{a}, \mathrm{b}: \mathrm{p}<0.05)$; different letters in the same line show statistical differences (X, Y: $\mathrm{p}<0.01 ; \mathrm{x}, \mathrm{y}$ : $\mathrm{p}<0.05)$.

old, chroma decreased from the first to the third postthawing day $(\mathrm{p}<0.01)$. In older horses, chroma decreased at the second day $(p<0.01)$ and then remained constant. Only in the first post-thawing day, horses slaughtered at 11 and 18 mo old showed greater chroma values $(\mathrm{p}<0.01)$. On the contrary, DRCS in meat from animals slaughtered at 11 and 18 mo showed greater chroma values than younger animals during post-thawing time $(\mathrm{p}<0.01)$.

Samples from animals slaughtered at 6 mo old showed lower haematin concentration than the ones obtained by animal slaughtered at 11 and $18 \mathrm{mo}(\mathrm{p}<0.05)$.

\section{DISCUSSION}

Freezing permits food products to be consumed several mo after production and is one of the most frequently used methods of preserve them (Haugen et al., 2006; Rajendran et al., 2006).

The colour of horse meat is strongly influenced by slaughtering age. Similar results have been obtained by other authors on buffalo (Tateo et al., 2007), bovine (Lengyel et al., 2003) and goat meat (Madruga et al., 1999).

On both the investigated surfaces, and particularly on DRCS, lightness values showed a decreasing trend with the increasing of the slaughtering age. Mancini and Hunt (2005) stated that this parameter, in fresh meat, was significantly 
influenced by meat chemical composition, and particularly by its water content and intramuscular lipids concentration. Probably, the lightness trend observed could be due to a reduction of meat water content with the increasing slaughtering age (Mancini and Hunt, 2005; Mortensen et al., 2006). Many authors (Schroeder et al., 1980; Vestergaard et al., 2000; Yang et al., 2002), reported in bovine meat an increase of lightness with the increasing of slaughtering age, stating that it is due to a greater intramuscular lipid content (Mancini and Hunt, 2005). However, horses tend to concentrate adipogenesis in the subcutaneous district rather than in the intramuscular one (Rossier and Berger, 1988). Probably, for these reason, meat lightness is influenced more by intramuscular water content than intramuscular lipid content in equine species (Palenik et al., 1980; Robelin et al., 1984). The increasing trend of lightness on DRCS observed in all slaughtering ages, but particularly on 6 mo old horses, could be due to a progressive breaking of muscular fibres during post-thawing time, with the passage of water from the intracellular to extracellular district (Yu et al., 2005; Mortensen et al., 2006). The NRCS didn't show variation of lightness during post-thawing time, probably because, as reported by Ramirez and Cava (2007), conditions of relative humidity remained stable during storage.

During post thawing time, redness and chroma on NRCS showed a falling trend. This is probably due to the biochemical phenomena which occurred with the exposition of myoglobin pigment to the air (Xiong et al., 2007). In fact, the myoglobin oxidation causes darkening processes on meat (Livingston and Brown, 1982; Wallace et al., 1982). The DRCS didn't show variation of redness and chroma during post-thawing time. Probably DRCS were less affected by the partial pressure of oxygen due to the less time of exposition to air, so they were less liable to undergo oxidizing processes (Tang et al., 2006; Tateo et al., 2006). Moreover, meat from younger animals showed lower values of redness and chroma. This coincide with the meat with the lower concentration of haematin that involves this colour aspects (Vestergaard et al., 2000; Gil et al., 2001).

Yellowness, on both DRCS and NRCS, is not affected by slaughtering age. Mancini and Hunt (2005) affirmed that $\mathrm{b}^{*}$ values are closely linked to quantity and quality aspects of intramuscular fat. Few variations linked to slaughtering ages could be an indirect indication of a qualitative modification of the intramuscular lipids (Realini et al., 2004).

Post-thawing time affected yellowness exclusively on NRCS. This is probably because of the development of lipid oxidization processes following the liberation of lipolithic enzymes in the intercellular interstices and with oxidereducing activities within the fibres (Motilva et al., 1993; Tang et al., 2006). Similar results were obtained by Wulf and Wise (1999) in bovine meat and by Tateo et al. (2007) in buffalo meat.

\section{CONCLUSION}

Consumer prefers meat that is light and has a low intensity of redness. From a chromatic perspective the thawed meat of IHDH foals slaughtered at 6 mo of age is that which best meets the market requirements. Since the qualitative aspects of the freezer-stored meat are not only to be explained by chromatic parameters, further studies on the post-thawing quality of horse meat are necessary. Besides, will be useful further studies aimed to clarify the mechanisms responsible of the chromatic changes in horse meat described in the present paper (fractions of myoglobin chemical form, lipid oxidative status, methmyoglobin reducing activity, oxygen consumption rate, microbial growth, drip lossess, ...), and the effect of different packaging techniques able to improve post-thawing horse meat colour changes.

\section{REFERENCES}

Brewer, M. S., L. G. Zhu, B. Bidner, D. J. Meisinger and F. K. McKeith. 2001. Measuring pork colour: effects of bloom time, muscle, $\mathrm{pH}$ and relationship to instrumental parameters. Meat Sci. 57:169-176.

Choe, J. H., Y. M. Choi, S. H. Lee, Y. J. Nama, Y. C. Jung, H. C. Park, Y. Y. Kim and B. C. Kim. 2009. The relation of blood glucose level to muscle fiber characteristics and pork quality traits. Meat Sci. 83:62-67.

CIE (Commission International d'Eclairage). 1986. Colourimetry, 2nd edition. Publication CIE, Vienna.

Gil, M., X. Serra, M. Gispert, A. M. Oliver, C. Snudo, B. Panea, J. L. Olleta, M. Campo, M. Olivan, K. Osoro, M. D. GarciaCachan, R. Cruz-Sagredo, M. Izquierdo, M. Espero and J. Piedrafita. 2001. The effect of breed-production systems on the myosin heavy chain 1 , the biochemical characteristics and the colour variables of Longissimus thoracics from seven Spanish beef cattle breeds. Meat Sci. 58:181-188.

Haugen, J. E., F. Lundby, J. P. Wold and A. Veberg. 2006. Detection of rancidity in freeze stored turkey meat using a commercial gas-sensor array system. Sensor Actuat. B-Chem. 116:78-84.

Hornsey, H. C. 1956. The colour of cooked cured pork. I. Estimation of the nitric oxide haem pigments. J. Sci. Food Agric. 7:534-542.

Jacob, R. H. and K. L. Thomson. 2012. The importance of chill rate when characterizing colour change of lamb meat during retail display. Meat Sci. 90:478-484.

Kannan, G., B. Kouakou and S. Gelaye. 2001. Colour changes reflecting myoglobin and lipid oxidation in chevron cuts during refrigerated display. Small Rumin. Res. 42:67-74.

Lengyel, Z., F. Husvéth, P. Polgár, F. Szabó and L. Magyar. 2003. Fatty acid composition of intramuscular lipids in various muscles of Holstein-Friesian bulls slaughtered at different ages. Meat Sci. 65:593-598. 
Livingston, D. J. and W. D. Brown. 1982. The chemistry of myoglobin and its reactions. Food Technol-Chicago. 35:244252.

Little, A. C. 1975. A Research note Off on a tangent. J. Food Sci. 40:410-411.

Madruga, M. S., S. G. B. Arruda and J. A. Nascimento. 1999. Castration and slaughter age effects on nutritive value of the "mestiço" goat meat. Meat Sci. 52:119-125.

Mancini, R. A., M. C. Hunt, K. A. Hachmeister, D. H. Kropf and D. E. Johnson. 2004. Ascorbic acid minimizes lumbar vertebrae discolouration. Meat Sci. 68:339-345.

Mancini, R. A. and M. C. Hunt. 2005. Current research in meat colour. Meat Sci. 71:100-121.

Mortensen, M., H. J. Andersen, S. B. Engelsen and H. C. Bertram. 2006. Effect of freezing temperature, thawing and cooking rate on water distribution in two pork qualities. Meat Sci. 72:34-42.

Motilva, M. J., F. Toldra, P. Nieto and J. Flores. 1993. Muscle lipolysis phenomena in the processing of dry-cured ham. Food Chem. (Chicago). 48:121-125.

Palenik, S., H. Biechova and O. Palanska. 1980. Chemical composition and quality of the meat of cold and warm blooded foals. Zivocisna Vyroba 25:269-278.

Rajendran, T., A. S. R. Anjaneyulu and N. Kondaiah. 2006. Quality and shelf life evaluation of emulsion and restructured buffalo meat nuggets at cold storage $\left(4 \pm 1^{\circ} \mathrm{C}\right)$. Meat Sci. 72:373-379.

Ramírez, R. and R. Cava. 2007. The crossbreeding of different Duroc lines with the Iberian pig affects colour and oxidative stability of meat during storage. Meat Sci. 77:339-347

Realini, C. E., S. K. Duckett, G. W. Brito, M. Dalla Rizza and D. De Mattos. 2004. Effect of pasture vs concentrate feeding with or without antioxidants on carcass characteristics, fatty acid composition, and quality of Uruguayan beef. Meat Sci. 66:567-577.

Robelin, J., L. Boccard, W. Martin-Rosset, M. Jussiaux and C. Trillaud-Geyl. 1984. Caracteristiques des carcasse set qualites de la vivande de cheval. In: Le Cheval. ReproductionSelection-Alimentation-Exploitation (Ed. R. Jarrige and W. Martin-Rosset). INRA Publications, Paris, France. pp. 601-610.

Rossier, E. and C. Berger. 1988. La Viande de Cheval: Des Qualites Indiscutables et Pourtant Meconnues. Cahiers de nutrition et de diététique 23:35-40.

SAS. 1998. Applied statistics and the SAS programming language. Cary, NC, USA: SAS Institute Inc.

Schroeder, J. W., D. A. Cramer, R. A. Bowling and C. W. Cook. 1980. Palatability, shelf-life and chemical differences between forage and grain-finished beef. J. Anim. Sci. 50:852-859.

Smith, G. C., K. E Belk, J. N. Sofos, J. D. Tatum and S. N. Williams. 2000. Economic implications of improved colour stability in beef. In: Antioxidants in muscle foods: Nutritional strategies to improve quality (Ed. E. A. Decker, C. Faustman and C. J. Lopez-Bote), Wiley Interscience, New York. pp. 397426.
Stivarius, M. R., F. W. Pohlman, K. S. McElyea and A. L. Waldroup. 2002. Effects of hot water and lactic acid treatment of beef trimmings prior to grinding on microbial, instrumental colour and sensory properties of ground beef during display. Meat Sci. 60:327-334.

Tang, J., C. Cameron, A. Faustman, R. A. Richard, M. Mancini, C. Melvin Mark Seyfert and M. C. Hunt. 2006. The effects of freeze-thaw and sonication on mitochondrial oxygen consumption, electron transport chain-linked metmyoglobin reduction, lipid oxidation, and oxymyoglobin oxidation. Meat Sci. 74:510-515.

Tateo, A., P. De Palo, B. Padalino and P. Centoducati. 2009. Artificially suckled IHDH (Italian Heavy Draught Horse) foals: In vivo performances and ethograms. Italian J. Anim. Sci. 8:724-726.

Tateo, A., P. De Palo, E. Ceci and P. Centoducati. 2008. Physicochemical properties of meat of Italian Heavy Draught Horses slaughtered at the age of eleven months. J. Anim. Sci. 86:1205-1214.

Tateo, A., P. De Palo, B. Padalino and P. Centoducati. 2005. Quality of carcasses in IHDH foals reared in the province of Bari (Italy). Italian J. Anim. Sci. 4:418-420.

Tateo, A., P. De Palo, F. D’Onghia and P. Centoducati. 2006. Rheological properties of horse meat from IHDH bred in the South of Italy. In: IX WEVA Congress, pp. 438-440.

Tateo, A., P. De Palo, N. C. Quaglia and P. Centoducati. 2007. Some qualitative and chromatic aspects of thawed buffalo (Bubalus bubalis) meat. Meat Sci. 76:352-358.

Vestergaard, M., M. Therkildsen, P. Henckel, L. R. Jensen, H. R. Andersen and K. Sejrsen. 2000. Influence of feeding intensity, grazing and finishing feeding on meat and eating quality of young bulls and the relationship between muscle fibre characteristics, fibre fragmentation and meat tenderness. Meat Sci. 54:187-195.

Yang, A., M. C. Lanari, M. J. Brewster and R. K. Tume. 2002. Lipid stability and meat colour of beef from pasture and grain fed cattle with or without vitamin E supplement. Meat Sci. 60:41-50.

Yu, L. H., E. S. Lee, J. Y. Jeong, H. D. Paik, J. H. Choi and C. J. Kim. 2005. Effects of thawing temperature on the physicochemical properties of pre-rigor frozen chicken breast and leg muscles. Meat Sci. 71:375-382.

Xiong, Y. L., O. E. Mullins, J. F. Stika, J. Chen, S. P. Blanchard and W. G. Moody. 2007. Tenderness and oxidative stability of post-mortem muscles from mature cows of various ages. Meat Sci. 77:105-113.

Wallace, W. J., R. A. Houtchens, J. C. Maxwell and S. Caughey. 1982. Mechanism of autoxidation for hemoglobins and myoglobins. J. Biol. Chem. 257:4966-4977.

Wulf, D. M. and J. W. Wise. 1999. Measuring muscle colour on beef carcasses using the $\mathrm{L}^{*} \mathrm{a} * \mathrm{~b} *$ colour space. J. Anim. Sci. $77: 2418-2427$. 